\title{
The ultrastructural organization of Acoela and their phylogenetic relationships
}

\begin{abstract}
Ya.l. Zabotin
Kazan (Volga region) Federal University, Kazan, 420008, Russia. E-mail: Yaroslav_Zabotin@, rambler.ru

ABSTRACT: Acoela represent one of the most spectacular taxa in animal kingdom. Their phylogenetic position as well as a taxonomic rank widely varies in zoological literature from the order of flatworms to the separate phylum within the deuterostomes or the sister taxon of all other bilaterians. One of the reasons of the absence of consensus among morphologists and molecular biologists is the insufficient amount of fine structural data on Acoela. In the present work the new ultrastructural features of four species of Acoela (Archaphanostoma agile, Otocelis rubropunctata, Symsagittifera japonica and Amphiscolops sp.) from different families are described. Along with the archaic characteristics the new apomorphic morphological features of epidermis, body wall musculature and central syncytial parenchyma of species studied were found. The cellular organization of acoels is characterized by the wide morphological diversity, however no significance of the secondarily simplification was found. The alternative views on phylogenetic affinities of Acoela are discussed, and the conclusion of progressive but not regressive evolution of this invertebrate group is proposed.

How to cite this article: Zabotin Ya.I. 2017. The ultrastructural organization of Acoela and their phylogenetic relationships // Invert. Zool. Vol.14. No.2. P.217-225. doi: 10.15298/ invertzool.14.2.17
\end{abstract}

KEY WORDS: Acoela, morphology, ultrastructure, systematics, phylogeny.

\section{Ультраструктурная организация бескишечных турбеллярий (Acoela) и их филогенетические отношения}

\section{Я.И. Заботин}

Казанский (Приволжский) федеральный университет, Казань, 420008, Россия. E-mail: Yaroslav_Zabotin@rambler.ru

РЕЗЮМЕ: Бескишечные турбеллярии (Acoela) представляют собой один из самых необычных таксонов животного царства. Их филогенетическое положение и таксономический ранг варьируют в зоологической литературе от отряда плоских червей до отдельного типа вторичноротых или до сестринского таксона по отношению ко всем остальным Bilateria. Одной из причин отсутствия единого мнения у морфологов и молекулярных биологов является недостаток данных по ультратонкому строению Acoela. В работе приводятся новые данные по ультраструктуре четырех видов Acoela (Archaphanostoma agile, Otocelis rubropunctata, Symsagittifera japonica и Amphiscolops sp.) из разных семейств. Наряду с архаическими особенностями описаны новые 
апоморфные особенности эпидермиса, мускулатуры стенки тела и центральной синцитиальной паренхимы у исследованных видов. Клеточная организация бескишечных турбеллярий отличается высоким морфологическим разнообразием, однако свидетельств их вторичного упрощения обнаружено не было. Обсуждаются альтернативные взгляды на филогенетические связи Acoela и приводится заключение о прогрессивной, а не регрессивной эволюции этой группы беспозвоночных.

Как цитировать эту статью: Zabotin Ya.I. 2017. The ultrastructural organization of Acoela and their phylogenetic relationships // Invert. Zool. Vol.14. No.2. P.217-225. doi: 10.15298/invertzool.14.2.17

КЛЮЧЕВЫЕ СЛОВА: Бескишечные турбеллярии (Acoela), морфология, ультраструктура, систематика, филогения.

\section{Introduction}

The taxon Acoela includes small predominantly marine (with just two known freshwater species as exceptions) worm-like invertebrates. Up to date about 380 species of Acoela is grouped into various number of families from 9 (Jondelius et al., 2011) to 19 (Hooge, Tyler, 2005). Classical morphologists considered them to be the most primitive members of the Bilateria (Ivanov, Mamkaev, 1973), or oppositely the secondarily simplified invertebrates, e.g. the paedomorphic descendants of advanced coelomate metazoans (Malakhov, 2009).

The taxonomic status of Acoela is also variable in different sources. For a long time they have been classified within class Turbellaria, subclass Archoophora (Ivanov, Mamkaev, 1973). Ehlers (1985) proposed the systematic revision of phylum Plathelminthes based on ultrastructural features. He revealed the class Turbellaria to be paraphyletic taxon lacking certain synapomorphies, and placed Acoela with closely related order Nemertodermatida in subphylum Acoelomorpha. According to the results of $18 \mathrm{~S}$ rDNA sequence, Ruiz-Trillo et al. (1999) removed Acoelomorpha from the phylum Plathelminthes and classified them as the sister taxon to all other Bilateria; although Philippe et al. (2011), based on multiple proteincoding genes sequence, surprisingly placed them within a superphylum Deuterostomia. Finally, the most relevant molecular and morphological data join the Acoelomorpha with another enig- matic phylum of worm-like invertebrates Xenoturbellida; the newly-erected taxon Xenacoelomorpha is transferred back to the basis of the Bilaterian phylogenetic tree (Cannon et al., 2016). So, up to date the phylogenetic position of this problematic taxon still remains unclear. One of the reasons of the absence of consensus among morphologists and molecular biologists is the insufficient amount of fine structural data on Acoela. So the aim of the present work is the ultrastructural study of cellular organization of Acoela with phylogenetic implications.

\section{Materials and methods}

Four species of Acoela were chosen for the present study: Archaphanostoma agile (Jensen, 1878) (Isodiametridae), Otocelis rubropunctata (Schmidt, 1852) (Otocelididae), Symsagittifera japonica (Kato, 1951) (Sagittiferidae) and Amphiscolops sp. (Convolutidae). S. japonica (formerly known as Convoluta japonica) and Amphiscolops sp. (described by Minegishi (1965) without a specific name) have never been studied on electron-microscopic level before. The specimens of $A$. agile were collected on the sandy littoral of various islands of Keretskii Archipelago (White Sea, Russia); the other species were collected on sandy littoral and algae of Mukaishima Island (Hiroshima Prefecture, Japan). The entire animals were fixed in $1 \%$ glutaraldehyde on $0.1 \mathrm{M}$ phosphate buffer. The preparation of the samples for the transmission electron microscopy (TEM) in- 
cluded post-fixation in $1 \%$ osmium tetraoxide on $0,1 \mathrm{M}$ phosphate buffer, dehydration from $30 \%$ to absolute alcohol and acetone, embedding in epon resin. Ultrafine cuts were made using ultramicrotome Reichert-Jung, contrasted with uranil-acetate and lead citrate and investigated using TEM JEM 100 CX in the Department of Zoology and General Biology of Kazan (Volga Region) Federal University (Kazan, Russia).

\section{Results}

\section{Epidermis and body wall muscula- ture}

The single-layered epidermis of all four species studied is lacking a basal membrane and weakly separated from parenchyma. The epidermis of Archaphanostoma agile consists of narrow cells $7-8 \mu \mathrm{m}$ high and belongs to noninsunk type, characterized by location of cell nuclei upper to the musculature (Fig. 1 A). Otocelis rubropunctata also possess non-insunk epidermis; its cells reach $13 \mu \mathrm{m}$ in height. Symsagittifera japonica and Amphiscolops sp. possess a typical insunk epidermis (Fig. $1 \mathrm{~B}$ ). Each epithelial cell is divided by the musculature on two parts - upper wide and flat terminal plate, about $6 \mu \mathrm{m}$ wide and $2 \mu \mathrm{m}$ high and lower basal part, containing nucleus about $4 \mu \mathrm{m}$ in diameter. The epidermal cells are connected by the cell junctions - desmosomes - in the terminal parts.

The external body surface of Acoela is covered by cilia, characterized by standard axoneme formula $9+2$. The kinetosome of each cilium possesses a single curved transversallystriated main rootlet up to $1 \mu \mathrm{m}$ in length (Fig. 1 $\mathrm{C}-\mathrm{E}, m r)$. Two very thin lateral rootlets go away from the curve of the main rootlet to the ends of the rootlets of neighboring cilia (Fig. $1 \mathrm{C}-\mathrm{E}, / r$ ). Also a very short caudal rootlet is present (Fig. $1 \mathrm{C}-\mathrm{E}, \mathrm{cr}$ ), from which the thin posterolateral microtubules go away to the curves of the rootlets of the neighboring cilia (Fig. $1 \mathrm{C}-\mathrm{E}, \mathrm{plm}$ ). In A. agile the posterolateral microtubules are ru- dimental, while in other species they are welldeveloped. In the cytoplasm of epidermal cells of three species (O. rubropunctata, S. japonica and Amphiscolops sp.) below the ciliary rootlets the multiple small transparent vacuoles (about 1 $\mu \mathrm{m}$ in diameter) are scattered (Fig. $1 \mathrm{~B}, \mathrm{C}, v$ ).

The body wall musculature of $A$. agile, $O$. rubropunctata and $S$. japonica consists of three layers of the smooth musculature - outer circular, middle diagonal and inner longitudinal muscles; the degree of development of each layer differs depending on the species. In $A$. agile the diagonal muscles sometimes are irregularly arranged. In O. rubropunctata the diagonal muscles are also rather poorly-differentiated. Oppositely, the all three muscle layers of $S$. japonica are well-developed. The nuclei of the myocytes reach $3 \mu \mathrm{m}$ in diameter.

The body wall musculature of Amphiscolops sp. is well-developed and differs from the above-mentioned species by unusual order of muscle layers: the diagonal muscles are located below the circular and longitudinal ones (Fig. 1 B). The outer circular layer is represented by the smooth muscles. The middle longitudinal and inner diagonal layers consist of the cross-striated muscle fibers. The myofibrils are transversally crossed by the electron dense striations resembling the Z-discs. The distance between the striations (which can be considered as the length of the sarcomere) is about $1.5 \mu \mathrm{m}$.

\section{Parenchyma}

In all four studied species of Acoela parenchyma is divided into peripheral and central zone (including the syncytium). The peripheral parenchyma of $A$. agile consists of three types of cells. There are elongated cells $(5-7 \mu \mathrm{m}$ in length) with large nucleus and electron transparent cytoplasm (Fig. $2 \mathrm{~A}$ ), the cells with dense cytoplasm and the small cells ( $3.5 \mu \mathrm{m}$ in length) with high nuclear-cytoplasmic ratio. The cells of central parenchyma are oval or amoeboid and reach $10 \mu \mathrm{m}$ in length; electron transparent cytoplasm contains the numerous mitochondria, dictyosomes of Golgi complex, channels of endoplasmic reticulum. The central syncy- 

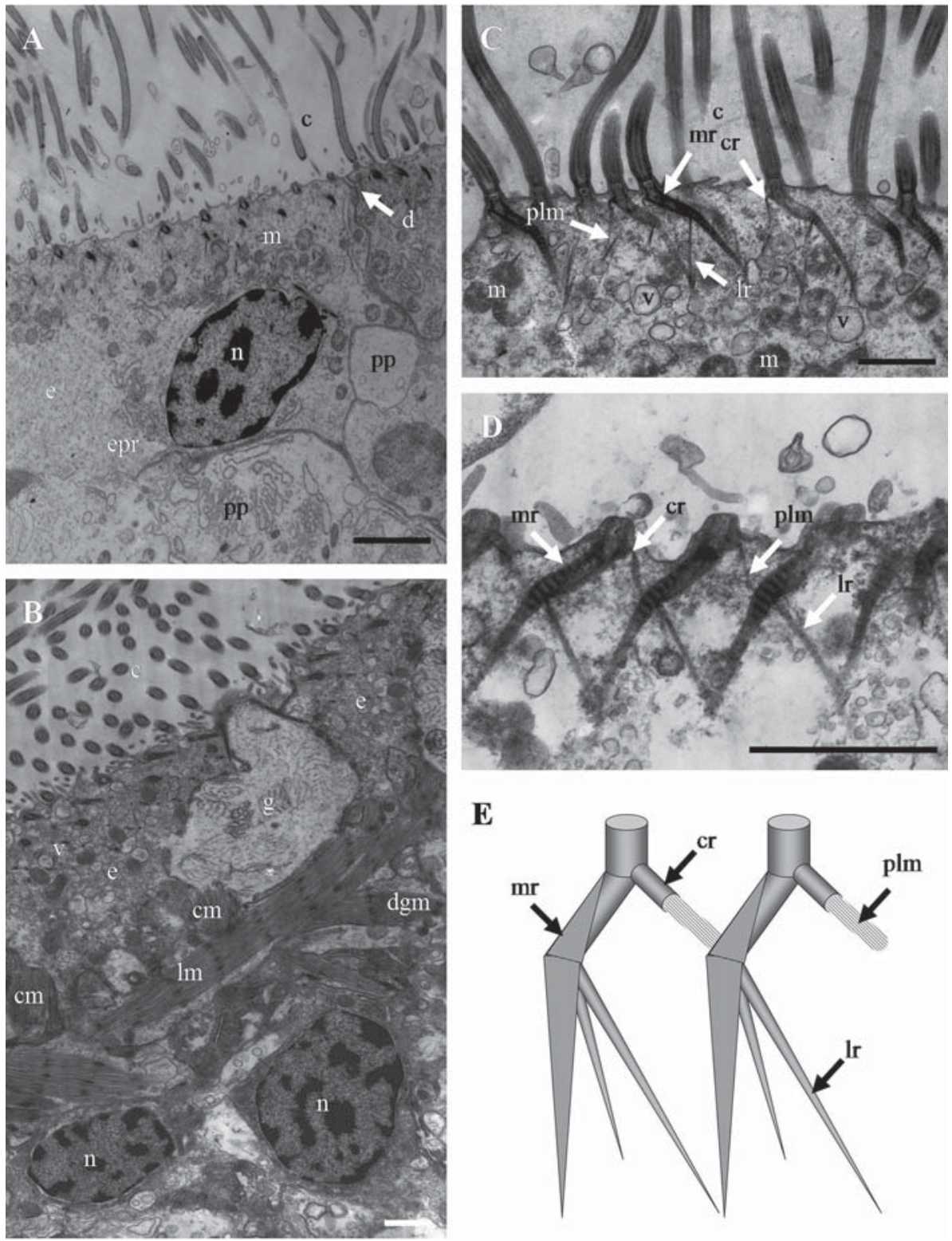

Fig. 1. The ultrastructure of epidermis and musculature of Acoela. A - non-insunk epidermis of Archaphanostoma agile; B — insunk epidermis and body wall musculature of Amphiscolops sp.; C — ciliary rootlets of epidermal cell of Otocelis rubropunctata; D - ciliary rootlets of epidermal cell of Amphiscolops sp.; E - schematic reconstruction of the ciliary rootlets of Acoela.

Abbreviations: $\mathrm{c}$ - cilia; $\mathrm{cm}$ - circular muscles; $\mathrm{cr}$ - caudal rootlet; $\mathrm{d}$ - desmosome; dgm — diagonal muscles; $\mathrm{e}$ - epidermal cell; epr — endoplasmic reticulum; $\mathrm{g}$ - gland; $1 \mathrm{~m}$ - longitudinal muscles; $1 \mathrm{r}$ - lateral rootlet; $\mathrm{m}$ mitochondria; $\mathrm{mr}$ - main rootlet; $\mathrm{n}$ - nucleus; $\mathrm{plm}$ — posterolateral microtubules; $\mathrm{pp}$ - peripheral parenchyma; $\mathrm{v}$ vacuole. Scale bar: $1 \mu \mathrm{m}$.

Рис. 1. Ультраструктура эпидермиса и мускулатуры Acoela. A - непогруженный эпидермис Archaphanostoma agile; В - погруженный эпидермис и мускулатура стенки тела Amphiscolops sp.; 
tium is represented by loose conglomeration of cell organoids and digestive vacuoles.

In O. rubropunctata the peripheral parenchyma includes four cell types: the oval cells (up to $7 \mu \mathrm{m}$ in diameter) with high nuclearcytoplasmatic ratio; the amoeboid cells (up to $10 \mu \mathrm{m}$ in diameter) with long processes; the irregular-shaped cells with the large nucleus; the small cells with unusual "inflated" perinuclear space. The cells of central parenchyma (13 $\mu \mathrm{m}$ in diameter) are amoeboid with long processes. The main volume of the central syncytial mass is occupied by the large (up to $4 \mu \mathrm{m}$ in diameter) digestive vacuoles and multilamellar bodies (Fig. 2 B).

The peripheral parenchyma of $S$. japonica consists of three cell types. There are large cells (up to $7 \mu \mathrm{m}$ in diameter) with the short processes; the smaller cells $(3.5 \mu \mathrm{m}$ in diameter) with the large nucleus with wide "inflated" perinuclear space and the smallest cells $(3 \mu \mathrm{m}$ in diameter) with electron dense cytoplasm and small amount of organelles. The cells of central parenchyma reach $4 \mu \mathrm{m}$ in diameter and possess various shapes (oval, elongated or amoeboid). The central syncytium of $S$. japonica is surrounded not only with parenchymal cells but also with the muscle cells (Fig. 2 C). The latter ones reach up to $4 \mu \mathrm{m}$ in cross section and contain the well-distinguished myofibrils. In the electron transparent central syncytial zone the solitary organelles (e.g., cell nuclei) and the fragments of the cell membranes are loosely scattered.

The peripheral parenchyma of Amphiscolops sp. is also composed of three cell types. Among them there are oval cells ( $4 \mu \mathrm{m}$ in diameter) with the large nucleus and the cytoplasm of the middle electron density; the larger cells (up to $12 \mu \mathrm{m}$ in diameter), amoeboid or star-shaped with multiple processes; the elongated cells (up to $4 \mu \mathrm{m}$ in length) with highly condensed chromatin. The central parenchymal cells are oval or round, reach $8 \mu \mathrm{m}$ in diameter and contain the solitary mitochondria and dictyosomes; these cells also form the central syncytium.

The parenchymal cells in all species studied are separated from each other by very thin layers of extracellular matrix up to $0.25 \mu \mathrm{m}$ wide. It is filled with electron dense material and sometimes contains the small vesicles, probably the results of the autophagic processes. In the parenchyma of S. japonica and Amphiscolops sp. the endosymbiotic green algae (zooxanthellae) were also observed. In some cases they were found to be digested by the central syncytium.

\section{Discussion}

The epidermis of the four species of Acoela studied in the present work can be defined as non-insunk (in Archaphanostoma agile and Otocelis rubropunctata) and the insunk one (in Symsagittiferajaponica and Amphiscolops sp.). Although Dorey (1965) originally classified the epidermis of $O$. rubropunctata as an insunk one, but according to our data, the nuclear parts of the cells never sink under the muscle layers. The multiple vacuoles of unclear function found in epidermal cells in all species studied (except A. agile) were also observed in Convoluta convoluta (Pedersen, 1964) and S. roscoffensis (formerly C. roscoffensis, Dorey, 1965).

The ultrastructure of the ciliary rootlets of all species studied is typical for Acoela but never occurs in flatworms. The epidermal cell cilium in most flatworms possesses two rootlets — the rostral and the caudal (sometimes called ventral) and the basal foot of kinetosome is reduced. Oppositely, in the Acoela these two rootlets are fused into the single main rootlet and additionally the pair of lateral rootlets ap-

C — корешки ресничек эпидермальной клетки Otocelis rubropunctata; D — корешки ресничек эпидермальной клетки Amphiscolops sp.; Е - схематическая реконструкция корешков ресничек Acoela.

Обозначения: с — реснички; cm — кольцевые мышцы; cr — задний корешок; d — десмосома; dgm — диагональные мышцы; е - клетка эпидермиса; epr — эндоплазматическая сеть; g — железа; $1 \mathrm{~m}$ - продольные мышцы; $1 \mathrm{r}$ - латеральные корешки; $\mathrm{m}$ - митохондрия; $\mathrm{mr}$ - главный корешок; $\mathrm{n}$ - ядро; plm - постеролатеральные микротрубочки; pp - периферическая паренхима; v — вакуоль. Масштаб: $1 \mu \mathrm{m}$. 

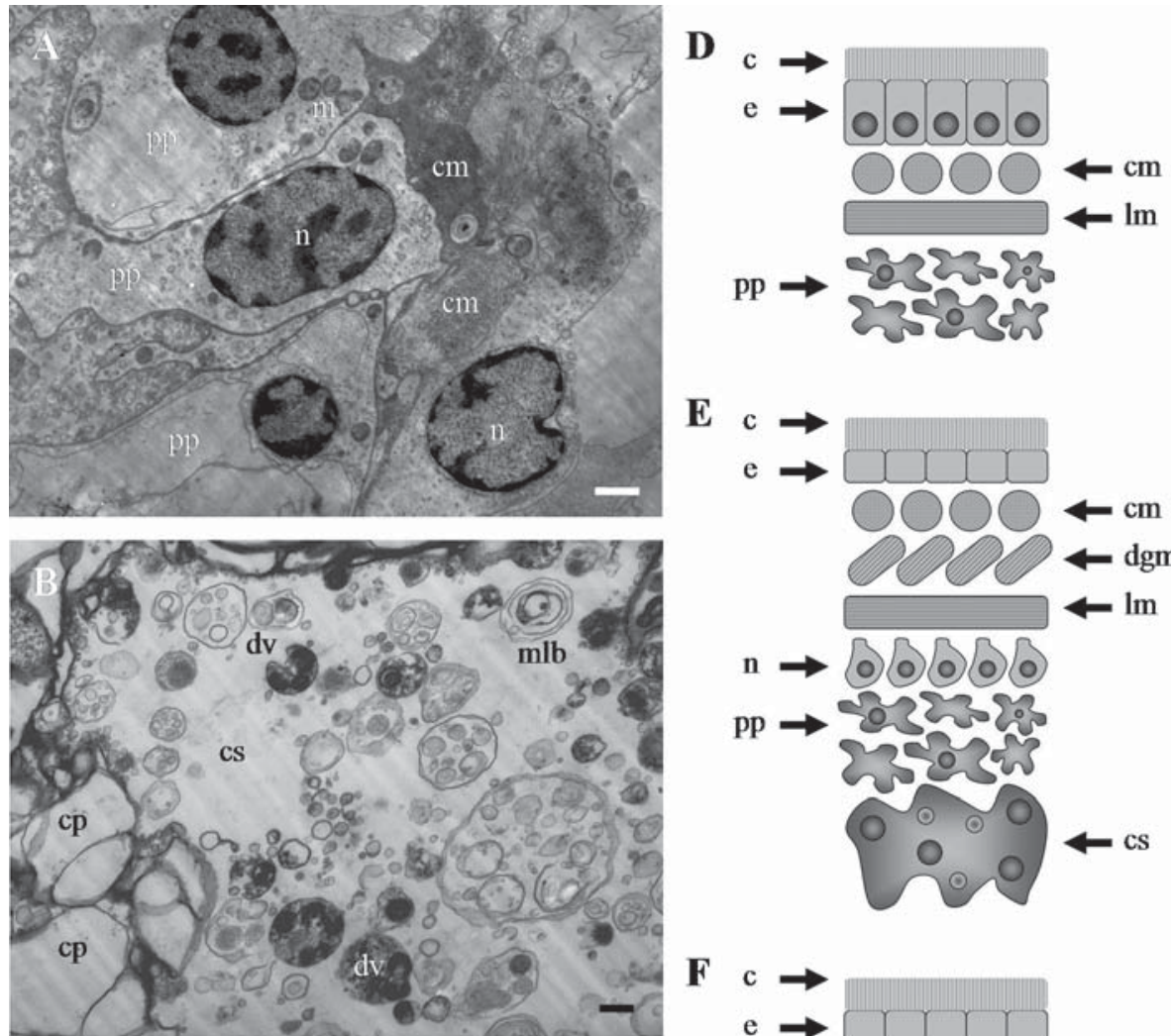

E

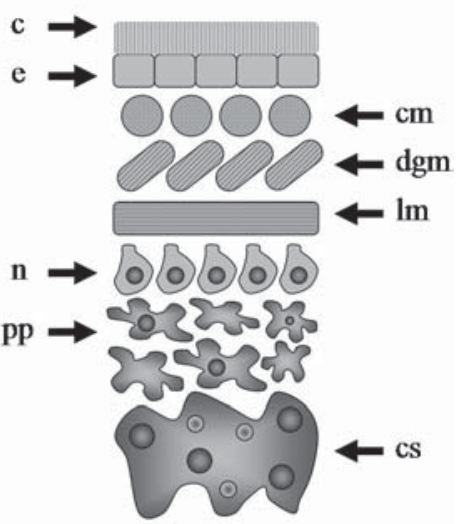

F

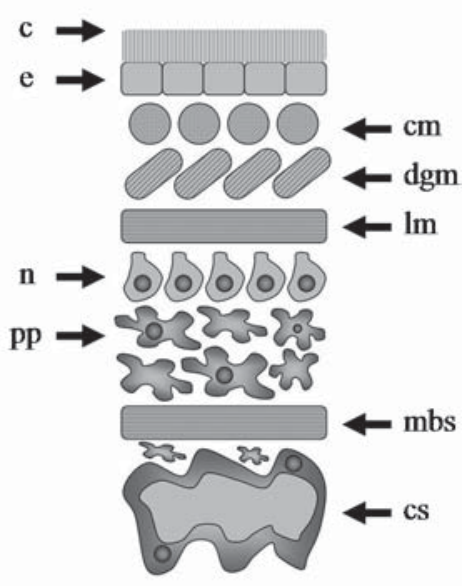

Fig. 2. The ultrastructure of parenchyma $(\mathrm{A}-\mathrm{C})$ and schematic reconstructions of body wall layers of Acoela (D-F). A - peripheral parenchyma (type I cells) of Archaphanostoma agile; B - central syncytium of Otocelis rubropunctata; C - central syncytium with muscular bound of Symsagittifera japonica; D - the plesiomorphic condition for Acoela: non-insunk epidermis, two-layered musculature and cellular parenchyma (exemplified by Paratomella rubra); E - the apomorphic condition for Acoela: insunk epidermis, threelayered musculature and central syncytium (in majority of acoel species); F - the autapomorphic condition for some derived families of Acoela: the muscular-bound central syncytium (exemplified by S. japonica). Abbreviations: $\mathrm{c}$ - cilia; $\mathrm{cm}$ - circular muscles; $\mathrm{cp}$ - central parenchyma; cs — central syncytium; dgm — diagonal muscles; $\mathrm{dv}$ - digestive vacuoles; $\mathrm{e}$ - epidermal cell; $1 \mathrm{~m}$ — longitudinal muscles; $\mathrm{m}$ - mitochondria; mbs — muscular bound of syncytium; mc - muscle cell; mlb - multilamellar body; $\mathrm{n}$ - nucleus; $\mathrm{pp}$ - peripheral parenchyma. Scale bar: $1 \mu \mathrm{m}$. 
pear; the caudal rootlet is homologous not to the above-mentioned caudal rootlet of other flatworms but to the basal foot of the kinetosome (see review in Ehlers, 1985; Raikova, 1991). The rootlet system of Nemertodermatida differs by the absence of the lateral rootlets (Tyler, Rieger, 1977) and in Xenoturbellida these two rootlets are convergent but not fused (Lundin, 1998). The structure of ciliary rootlets and the pattern of the ending of the epidermal cilia axoneme represent the synapomorphies of the Acoelomorpha (Ehlers, 1985). The monophyly of Xenacoelomorpha is proposed on the basis of the peculiarities of epidermal cilia and their rootlets (Lundin, 1998) and the modern molecular data (Cannon et al., 2016). However the Xenoturbellida significantly differ from Acoela by the development of epithelized intestine, the intraepidermal diffuse nervous system without a cerebral ganglion (Raikova et al., 2000), the absence of copulatory organs, the external insemination and the primitive uniflagellate spermatozoa (Obst et al., 2011). Thus, to our opinion, the phylogenetic relationships of Acoelomorpha and Xenoturbellida still remain debatable.

Raikova (1991) supposed that the plesiomorphic condition of the epidermal ciliary rootlets of the common ancestor of Acoelomorpha and Plathelminthes (or probably of Bilateria in general) was the presence of the separated rostral and caudal rootlets and the well-developed basal foot of the kinetosome. Concerning that, the fusion of both these rootlets into a single main rootlet and the independent origin of the caudal rootlet from the basal foot should be considered as an apomorphy for the whole taxon Acoela.
The architectonics of body wall musculature is used as a taxonomic character in acoel phylogenetics. In the basal families Diopisthoporidae, Paratomellidae and Solenofilomorphidae the diagonal muscles are absent and the whole body musculature includes only the outer circular and the inner longitudinal ones (Hooge, Tyler, 2006). The higher acoel families possessing the crosslike arrangement of diagonal musculature and the U-shaped muscles, surrounding the mouth opening are now grouped within a taxon Crucimusculata (Jondelius et al., 2011).

All acoel species investigated in the present work possess the typical number and order of the muscle layers for the crucimusculates except the Amphiscolops sp. This species is characterized by the inner position of the diagonal muscles. It should be mentioned that similar unusual order of muscle layers (circular, longitudinal, diagonal) was shown for another convolutid Oxyposthia praedator (Ivanov, 1952). Moreover in Amphiscolops sp. the cross-striated musculature was unexpectedly found. Previously the cross-striated muscles were described only in light-optical level in $O$. sachalinensis, Ox. praedator (Ivanov, 1952) and $C$. convoluta (Westblad, 1948), but the ultrastructural investigations of the latter species by Pedersen (1964) didn't confirm that. Raikova (1989) also define the acoel musculature as a smooth one, but in some cases she describes the dense striations of myofibrils as the homologues of the Z-discs. Concerning that, to our opinion, the origin of cross-striated musculature within the Acoela is highly probable, especially in the most advanced acoel family Convo-

Рис. 2. Ультраструктура паренхимы (A-C) и схематические реконструкции стенки тела Acoela (DF). А - периферическая паренхима (клетки I типа) Archaphanostoma agile; В — центральный синцитий Otocelis rubropunctata; C — центральный синцитий с мышечной обкладкой Symsagittifera japonica; D - плезиоморфное состояние Acoela: непогруженный эпидермис, двухслойная мускулатура и клеточная паренхима (на примере Paratomella rubra); E — апоморфное состояние Acoela: погруженный эпидермис, трехслойная мускулатура и центральный синцитий (у большинства видов Acoela); F - аутапоморфное состояние некоторых семейств Acoela: центральный синцитий с мышечной обкладкой (на примере $S$. japonica).

Обозначения: с — реснички; cm — кольцевые мышцы; ср — центральная паренхима; cs — центральный синцитий; dgm - диагональные мышцы; dv - пищеварительные вакуоли; е — клетка эпидермиса; $1 \mathrm{~m}$ продольные мышцы; $\mathrm{m}$ - митохондрия; mbs - мышечная обкладка синцития; mc — мышечная клетка; mlb — мультиламеллярное тело; $\mathrm{n}$ — ядро; рр — периферическая паренхима. Масштаб: $1 \mu \mathrm{m}$. 
lutidae (Jondelius et al., 2011) the Amphiscolops sp. belongs to.

Summarizing all this data, we can conclude that the non-insunk epidermis, the absence of diagonal muscles and the presence of the exclusively smooth musculature, widely distributed in the archaic acoels, represent the plesiomorphic condition for the whole taxon (Fig. 2 D). In a contrast, in the advanced acoel families the non-insunk epidermis is usually replaced by the insunk one; the body wall musculature differentiates into the three layers and (at least in some species such as Amphiscolops sp.) the crossstriated muscles appear. These ultrastructural peculiarities can be considered the progressive apomorphic condition for Acoela (Fig. 2 E).

The literary and original ultrastructural data reveal the high diversity of cells in parenchyma of Acoela. E.g., the parenchyma of C. convoluta consists of three cell types in the peripheral zone and two types in the central one (Pedersen, 1964). Mamkaev and Markosova (1979) described four cell types in the parenchyma of $O x$. praedator: the large amoeboid cells (also modified into the syncytium), the poorly-differentiated cells (neoblasts), the reserve cells and the glandular cells. Smith (1981) described in the parenchyma of Convoluta sp. the central syncytium and three types of so-called "wrapping cells". The combination of cell types and their quantitative composition in the parenchyma can be considered as the specific characters.

The syncytial structure of digestive system is undoubtedly one of the modular features of cellular organization of Acoela. In one of the most primitive acoel species Paratomella rubra the syncytial structures are absent and the parenchyma consists only of cells (Smith, Tyler, 1985). According to the modern phylogenetic analysis, the family Paratomellidae represents the sister taxon to all other acoels except the Diopisthoporidae (Jondelius et al., 2011). In the majority of acoel species the central syncytium is always present permanently or at least temporarily during the process of food digestion (Smith, Tyler, 1985; Raikova, 1987).

Finally, in the some species of Acoela the examples of deeper specialization of digestive system are described. Among them there is the formation of the solitary non-epithelized digestive cavity in Actinoposthia beklemischevi. According to the ultrastructural data (Raikova, 1987), this cavity is surrounded by the temporary syncytial structures and is filled with the cellular derivates and the membrane-bound vesicles. The typical parenchymal cells are separated from syncytium by the muscle bound, protecting them from its phagocytic activity (Raikova, 1987). The muscle-bound cavity of $A$. beklemischevi and the central syncytium described here for $S$. japonica look similar in the electron micrographs so it is possible that they both represent the different physiological conditions of the same structure. The muscle-bound syncytium is also supposed to assume the supportive function along with the traditional digestive one. These cases exemplify the high degree of integration between the parenchyma and musculature within the acoel organism. It should be notified that Actinoposthiidae and Convolutidae (including the members of the former Sagittiferidae family, to authors' opinion) nowadays occupy the derived positions on the phylogenetic tree of Acoela (Jondelius et al., 2011).

The evolutionary-morphological analysis of literary and original data shows that plesiomorphic condition of digestive system of Acoela is represented by the exclusively cellular construction of the parenchyma (exemplified by $P$. rubra, Fig. 2 D). With increasing of body size and respectively the size of ingested prey the archaic mode of phagocytic cellular digestion became non-effective. The intestine-less Acoela have "solved" this problem by unique way by the syncytial transformation of the central parenchyma. Thus the development of the central syncytium is considered to be the apomorphic condition for this taxon (Fig. 2 E). Finally, the origin of the muscular bound of syncytium in some representatives of Acoela (e.g., A. beklemischevi and $S$. japonica) can probably be considered the autapomorphic condition for the derived families of Acoela (Fig. 2 F).

The general conclusions can be summarized as follows. The present study revealed the new 
ultrastructural features of Acoela which can be identified as apomorphic characters, such as the origin of cross-striated musculature in Amphiscolops sp. and the central syncytium with the muscular bound in S. japonica. So the cellular organization of Acoela is characterized by the wider morphological diversity than previously supposed, however no significance of the secondarily simplification was found. According to the literary and original data, the Acoela are considered one of the most primitive bilaterian animals, and their evolution, to our opinion, can be defined as progressive, but not regressive.

\section{References}

Cannon J.T., Vellutini B.C., Smith III J., Ronquist F., Jondelius U., Hejnol A. 2016. Xenacoelomorpha is the sister group to Nephrozoa // Nature. Vol.530. P.89-93.

Dorey A.E. 1965. The organization and replacement of epidermis in acoelous turbellarians // Quarterly Journal of Microscopical Science. Vol.106. P.147-172.

Ehlers U. 1985. Das Phylogenetische System der Plathelminthes. Stuttgart, New York: Gustav Fischer Verlag. $317 \mathrm{~S}$.

Hooge M., Tyler S. 2005. New tools for resolving phylogenies: a systematic revision of Convolutidae (Acoelomorpha, Acoela) // Journal of Zoological Systematics and Evolutionary Research. Vol.43. No.2. P.100113.

Hooge M., Tyler S. 2006. Concordance of molecular and morphological data: the example of the Acoela // Integrative and Comparative Biology. Vol.46. No.2. P.118-124.

Ivanov A.V. 1952. [Acoel turbellarians (Acoela) of southern coast of Sakhalin] // Trudy Zoologicheskogo Instituta AN SSSR. Vol.12. P.40-132 [in Russian].

Ivanov A.V., Mamkaev Yu.V. 1973. [Turbellarians (Turbellaria), their origin and evolution]. Leningrad: Nauka. 221 p. [in Russian].

Jondelius U., Wallberg A., Hooge M., Raikova O.I. 2011. How the worm got its pharynx: phylogeny, classification and Bayesian assessment of character evolution in Acoela // Systematic Biology. Vol.60. No.6. P.845871.

Lundin K. 1998. The epidermal ciliary rootlets of Xenoturbella bocki (Xenoturbellida) revisited: a new support for a possible kinship with Acoelomorpha (Platyhelminthes) // Zoologica Scripta. Vol.27. No.3. P.263270 .

Malakhov V.V. 2009. [Revolution in zoology: new system of Bilateria] // Priroda. No.3. P.40-54 [in Russian].
Mamkaev Yu.V., Markosova T.G. 1979. [Electron microscopic investigation of parenchyma of acoel turbellarians] // Trudy Zoologicheskogo Instituta AN SSSR. Vol.84. P.7-12 [in Russian with English summary].

Minegishi H. 1965. [Acoela-Turbellaria] // New Illustrated Encyclopedia of the Fauna of Japan, Part I. Tokyo: Hokuryu-kan Publ. P.311-312 [in Japanese].

Obst M., Nakano H., Bourlat S.J., Thorndyke M.C., Telford M.J., Nyengaard J.R., Funch P. 2011. Spermatozoon ultrastructure of Xenoturbella bocki (Westblad 1949) // Acta Zoologica (Stockholm). Vol.92. P.109115.

Pedersen K.J. 1964. The cellular organization of Convoluta convoluta, an Acoel turbellarian: a cytological, histochemical and fine structural study // Zeitschrift für Zellforschung. Vol.64. P.655-687.

Philippe H., Brinkmann H., Copley R., Moroz L.L., Nakano H., Poustka A., Wallberg A., Peterson K., Telford M. 2011. Acoelomorph flatworms are deuterostomes related to Xenoturbella // Nature. Vol.470. P.255-258.

Raikova O.I. 1987. [Ultrastructural organization of the digestive system of the acoel turbellarian Actinoposthia beklemischevi Mamkaev] // Trudy Zoologicheskogo Instituta AN SSSR. Vol.167. P.72-78 [in Russian with English summary].

Raikova O.I. 1989. [Comparative investigation of ultrastructure of the acoel turbellarians]. PhD thesis. Leningrad, Zoologicheskii Institut AN SSSR. 23 p. [in Russian].

Raikova O.I. 1991. [On phylogenetic significance of turbellarian ultrastructural characters] // Trudy Zoologicheskogo Instituta AN SSSR. Vol.241. P.26-52 [in Russian with English summary].

Raikova O.I., Reuter M., Jondelius U., Gustafsson M.K.S. 2000. An immunocytochemical and ultrastructural study of the nervous and muscular systems of Xenoturbella westbladi (Bilateria inc. sed.) // Zoomorphology. Vol.120. P.107-118.

Ruiz-Trillo I., Riutort M., Littlewood D., Herniou E., Baguna J. 1999. Acoel flatworms: earliest extant bilaterian metazoans, not members of Platyhelminthes // Science. Vol.283. P.1919-1923.

Smith J.P.S. 1981. Fine-structural observations on the central parenchyma in Convoluta sp. // Hydrobiologia. Vol.84. P.259-265.

Smith J.P.S., Tyler S. 1985. The acoel turbellarians: kingpins of metazoan evolution or a specialized offshoot? // S. Conway Morris, J.D. George, R. Gibson, H.M. Platt (eds.). Origins and relationships of lower invertebrates. Oxford: Clarendon Press. P.123-142.

Tyler S., Rieger R. 1977. Ultrastructural evidence for systematic position of Nemertodermatida (Turbellaria) // Acta Zoologica Fennica. Vol.154. P.193-207.

Westblad E. 1948. Studien über skandinavische Acoela. V // Arkiv för Zoologi. Bd.41A. H.7. S.1-82.

Responsible editor E.N. Temereva 